University of Nebraska - Lincoln

DigitalCommons@University of Nebraska - Lincoln

Papers in the Earth and Atmospheric Sciences

Earth and Atmospheric Sciences, Department of

2001

Basicranial Anatomy of the Living Linsangs Prionodon and Poiana (Mammalia, Carnivora, Viverridae), with Comments on the Early Evolution of Aeluroid Carnivorans

Robert M. Hunt Jr.

University of Nebraska-Lincoln, rhunt2@unl.edu

Follow this and additional works at: https://digitalcommons.unl.edu/geosciencefacpub

Part of the Earth Sciences Commons

Hunt, Robert M. Jr., "Basicranial Anatomy of the Living Linsangs Prionodon and Poiana (Mammalia, Carnivora, Viverridae), with Comments on the Early Evolution of Aeluroid Carnivorans" (2001). Papers in the Earth and Atmospheric Sciences. 549. https://digitalcommons.unl.edu/geosciencefacpub/549

This Article is brought to you for free and open access by the Earth and Atmospheric Sciences, Department of at DigitalCommons@University of Nebraska - Lincoln. It has been accepted for inclusion in Papers in the Earth and Atmospheric Sciences by an authorized administrator of DigitalCommons@University of Nebraska - Lincoln. 


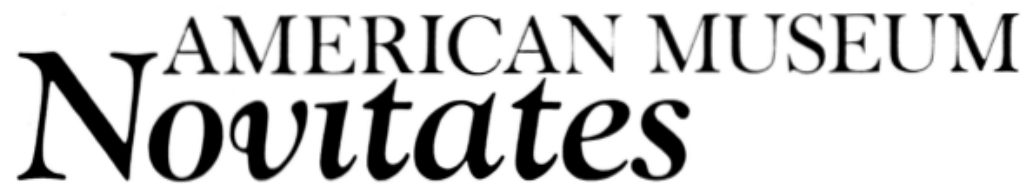

PUBLISHED BY THE AMERICAN MUSEUM OF NATURAL HISTORY CENTRAL PARK WEST AT 79TH STREET, NEW YORK, NY 10024 Number 3330, 24 pp., 10 figures, 2 tables

April 26, 2001

\section{Basicranial Anatomy of the Living Linsangs Prionodon and Poiana (Mammalia, Carnivora, Viverridae), with Comments on the Early Evolution of Aeluroid Carnivorans}

ROBERT M. HUNT, JR. ${ }^{1}$

\section{CONTENTS}

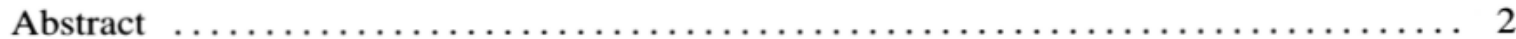

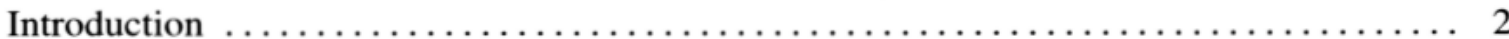

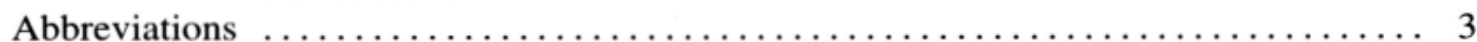

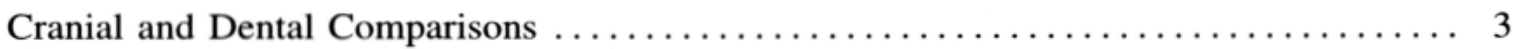

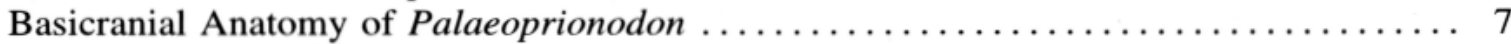

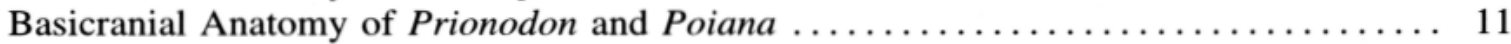

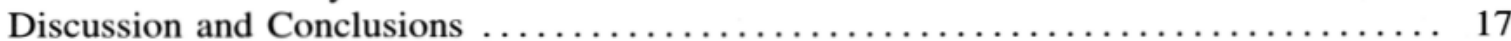

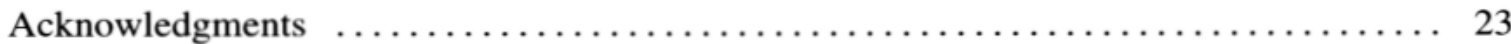

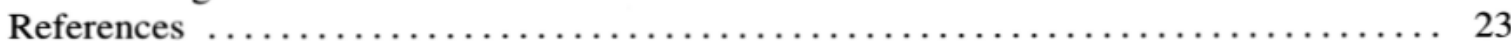

${ }^{1}$ Research Associate, Division of Paleontology, American Museum of Natural History; Professor, Geological Sciences, and Curator, Vertebrate Paleontology, University of Nebraska, Lincoln, NE 68588-0549. 


\section{ABSTRACT}

The living Asian linsang, Prionodon pardicolor, shares marked anatomical similarities in basicranium and dentition with the extinct Oligocene aeluroid, Palaeoprionodon lamandini, from the Quercy fissures, France. The living African linsang, Poiana richardsoni, is similar yet slightly more derived in basicranial traits relative to Prionodon pardicolor, and also has basicranial and dental features indicating a relationship to the living genets (Genetta). The basicranial and auditory anatomy of a series Palaeoprionodon-Prionodon-Poiana can be interpreted as a morphocline showing the progressive alteration of the form of the petrosal and auditory bulla from the plesiomorphic aeluroid state in the Quercy fossils to a derived condition typical of the linsangs (Prionodon, Poiana) and living genets (Genetta). The basicranial anatomy of Genetta, including the structure of the petrosal and auditory bulla, is typical of other species of the Viverridae. The other lineages of living viverrids are believed to have undergone a similar transformation in their basicranial anatomical pattern from the plesiomorphic state present in Oligocene aeluroids, exemplified by Palaeoprionodon, to the modern patterns typical of the living subfamilies (including the endemic Malagasy viverrid genera).

\section{INTRODUCTION}

African and Asian linsangs of the family Viverridae are living, nocturnal aeluroid carnivorans, occupying forested environs in the Old World tropics (fig. 1). The African linsang (Poiana Gray, 1864) is represented by one or at most two species in west Africa. Poina richardsoni and $P$. leightoni are distributed from Liberia to northern Zaire, and the island of Fernando Po (Bioko), according to Rosevear (1974). They are considered here as a single species, $P$. richardsoni, following Pocock (1908), who recognized leightoni as a subspecies of richardsoni. The Asian linsangs (Prionodon Horsfield, 1822) are considered to be more diverse: one species (the spotted linsang, $P$. pardicolor) is found from Nepal to Indochina, and a second species (the banded linsang, $P$. linsang) reported from Thailand and the Malay Peninsula into Sumatra, Java, and Borneo (Nowak, 1991). Linsangs nest above ground and eat insects, small vertebrates, and some plant material (Rosevear, 1974).

The Old World linsangs are of particular interest because of their evident anatomical similarity in cranial and dental features to one of the oldest fossil representatives of the aeluroid Carnivora, Palaeoprionodon lamandini, from the Oligocene fissure deposits of Quercy, France (Teilhard de Chardin, 1915; Gregory and Hellman, 1939). A recent study of Palaeoprionodon and other closely related primitive aeluroids (Stenoplesictis, Stenogale, Proailurus) from the Oligocene and early Miocene of western Europe identified a ple- siomorphic basicranial pattern common to these aeluroid genera (Hunt, 1998). As a result, I became interested to learn whether living linsangs have retained throughout the mid- and later Cenozoic the archaic basicranial pattern of these Quercy aeluroids, and in particular, whether they retain the pattern found in Palaeoprionodon, which has often been allied with the Asian linsangs of the genus Prionodon (Teilhard de Chardin, 1915, Gregory and Hellman, 1939).

The living African and Asian linsangs are rare animals: Prionodon pardicolor and $P$. linsang are listed as endangered (by the Convention on International Trade in Endangered Species, and by the U.S. Department of the Interior). Although the eastern population of Poiana richardsoni is not reported as endangered, the western population is listed by the IUCN (International Union for Conservation of Nature) as of indeterminate status (Nowak, 1991); whether these eastern and western groups are in contact through the tropical forest belt is uncertain-Rosevear (1974) considered them among the rarest of African mammals. Therefore, the opportunity to dissect the auditory region and describe the basicranial anatomy of both Poiana richardsoni and Prionodon pardicolor was fortuitous and timely. Are the linsangs "living fossils"? This study considers the possibility that linsangs are relicts of the Oligocene aeluroid fauna, preserving a basicranial morphology from a time when the Aeluroidea were in an initial phase of their great Eurasian radiation. 


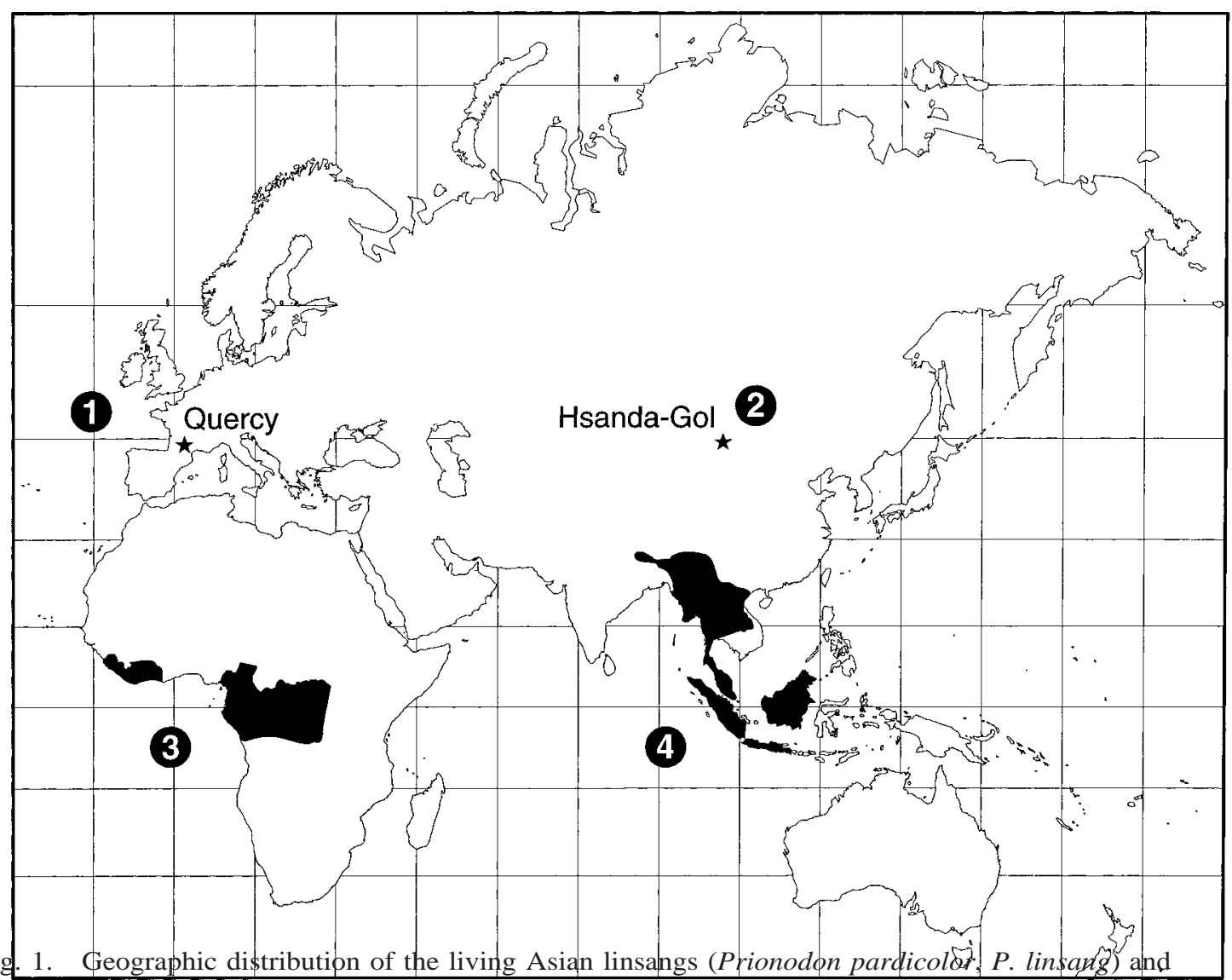

Fig. 1. Geographic distribution of the living Asian linsangs (Prionodon pardicoldst, P. linsang $g$ ) and African linsang (Poiana richardsoni), and the Eurasian localities that have produced fossils of the
Oligocene aeluroid Palaeoprionodon. 1, Palaeoprionodon lamandini, Quercy fissures, France; 2 , Hsanda Gol, Mongolia (?Palaeoprionodon); 3, Poiana richardsoni leightoni (western area), P. r. richardsoni (eastern area); 4, Prionodon pardicolor (northern area), Prionodon linsang (southern area).

\section{AbBreviations}

\section{Anatomical}

A alisphenoid

a "apron" of petrosal

ac alisphenoid canal (posterior opening)

BO basioccipital

BS basisphenoid

c common opening for the hypoglossal and posterior lacerate foramina in Poiana

d depression in basisphenoid for internal carotid loop

E caudal entotympanic

F facet on petrosal promontorium for ectotympanic

fo foramen ovale

gf postglenoid foramen ic

$\mathrm{L}$

$\mathrm{m}$

$\mathrm{P}$

plf

$\mathrm{pp}$

$\mathrm{R}$

rp

SQ

$\mathrm{T}$

tf

tt

$\mathrm{V}$ hypoglossal (condyloid) foramen internal carotid artery middle lacerate foramen mastoid petrosal posterior lacerate foramen paroccipital process of the exoccipital rostral entotympanic rugose surface of petrosal promontorium for attachment of the caudal entotympanic in Nandinia squamosal ectotympanic flange of the ventral process thinned by appression of the caudal entotympanic tensor tympani fossa ventral process of the petrosal promontorium 
x line of caudal entotympanic attachment to ectotympanic

Z contact of ectotympanic flange with petrosal promontorium

\section{Institutional}

AMNH American Museum of Natural History, New York (Department of Mammalogy)

FMNH Field Museum of Natural History, Chicago (Department of Mammals)

MNHN Muséum National d'Histoire Naturelle, Paris

\section{CRANIAL AND DENTAL COMPARISONS}

Cranial measurements of Prionodon, Poiana, and two skulls of Quercy Palaeoprionodon illustrate their similarity in size and proportion (table 1). All four skulls have a basilar length of $\sim 6-7 \mathrm{~cm}$ and display a similar form (figs. 2, 3): a slender, tapering rostrum; a gradually ascending forehead; and relatively large, wide orbits in which the anterior part is floored by the maxilla (fig. 3). The braincase is conspicuously expanded relative to the narrow rostrum, and the surface of the braincase indistinctly registers the topography of the neocortex. The cerebrum has not grown backward to cover the cerebellum in Prionodon and the Quercy skulls, and this is reflected in a distinct separation between the anterior and posterior parts of the braincase (a constriction in the skull occurs between the two regions). In Poiana there is a somewhat greater posterior overgrowth of the cerebellum by the cerebrum than in Prionodon. A triangular occiput is common to all four skulls; in the midline the vermis of the cerebellum produces a low elevation dorsal to the foramen magnum. A cranial endocast of Prionodon pardicolor has been described and figured by Radinsky (1975), comparing it with that of Poiana and other living viverrids.

In the living linsangs and in the plesiomorphic Quercy (Palaeopriondon, Stenoplesictis) and St.-Gérand (Stenogale) aeluroids, the foramen rotundum, orbital fissure, and optic foramen are deeply recessed in the sphenoid in a common elliptical depression located in the posteroventral orbital wall. In these carnivorans, the interorbital partition (formed by the right and left orbitosphenoids) is thin and narrow at this locus and probably represents the primitive aeluroid condition for the emergence of cranial nerves $\mathrm{V}_{1}, \mathrm{~V}_{2}$, and the optic nerve from the braincase. The optic foramen lies in close proximity to the orbital fissure in these aeluroids, in contrast to many arctoid carnivorans in which the optic foramen is placed farther forward along the orbital wall.

An alisphenoid canal is present, its posterior opening placed a few millimeters anterior to the foramen ovale. In Prionodon and Poiana the maxillary branch of the trigeminal nerve $\left(\mathrm{V}_{2}\right)$ exits the braincase through the small foramen rotundum in the cranial wall and emerges within the alisphenoid canal. Both $\mathrm{V}_{2}$ and the blood vessels traveling in the canal exit the skull directly below the orbital fissure at the anterior opening of the canal, which sometimes is confused with the true foramen rotundum. ${ }^{2}$ This arrangement is also true of Genetta. Palaeoprionodon, although somewhat damaged in the orbital region, appears to have been very similar to the living linsangs in the configuration of the orbital wall and the placement of these foramina (Hunt, 1998: fig. 4A).

The palate of the linsangs and Palaeoprionodon is triangular in ventral view, with a narrow anterior part that expands to its maximum width between the upper carnassials (fig. 2B). The upper dentition of these genera is delicate: the incisors are uniform in

\footnotetext{
${ }^{2}$ My identification of these foramina follows the interpretation put forward earlier by Pocock (1916a), based upon his detailed skull dissections. In many carnivoran species, including the living linsangs, $\mathrm{V}_{2}$ passes through the cranial wall via a small foramen that opens into the alisphenoid canal (this canal always lies external to the braincase and has anterior and posterior apertures). Pocock regarded the hidden internal opening in the cranial wall for $\mathrm{V}_{2}$ as the true foramen rotundum, and the more visible external opening that transmits $\mathrm{V}_{2}$, once it has joined with the vessels of the alisphenoid canal, as the anterior aperture of the alisphenoid canal. Thus, in some carnivorans with an alisphenoid canal (alar canal of Miller et al., 1964), the foramen rotundum cannot be seen when looking at the orbit, but remains entirely hidden by the bony exterior wall of the alisphenoid canal. However, in some pinnipeds (e.g., otariid Zalophus) the alisphenoid canal does not incorporate the true foramen rotundum for $\mathrm{V}_{2}$ but remains a separate bony tube, and in this case the anterior opening of the alisphenoid canal and the foramen rotundum actually appear as separate openings visible in the posterior orbit.
} 

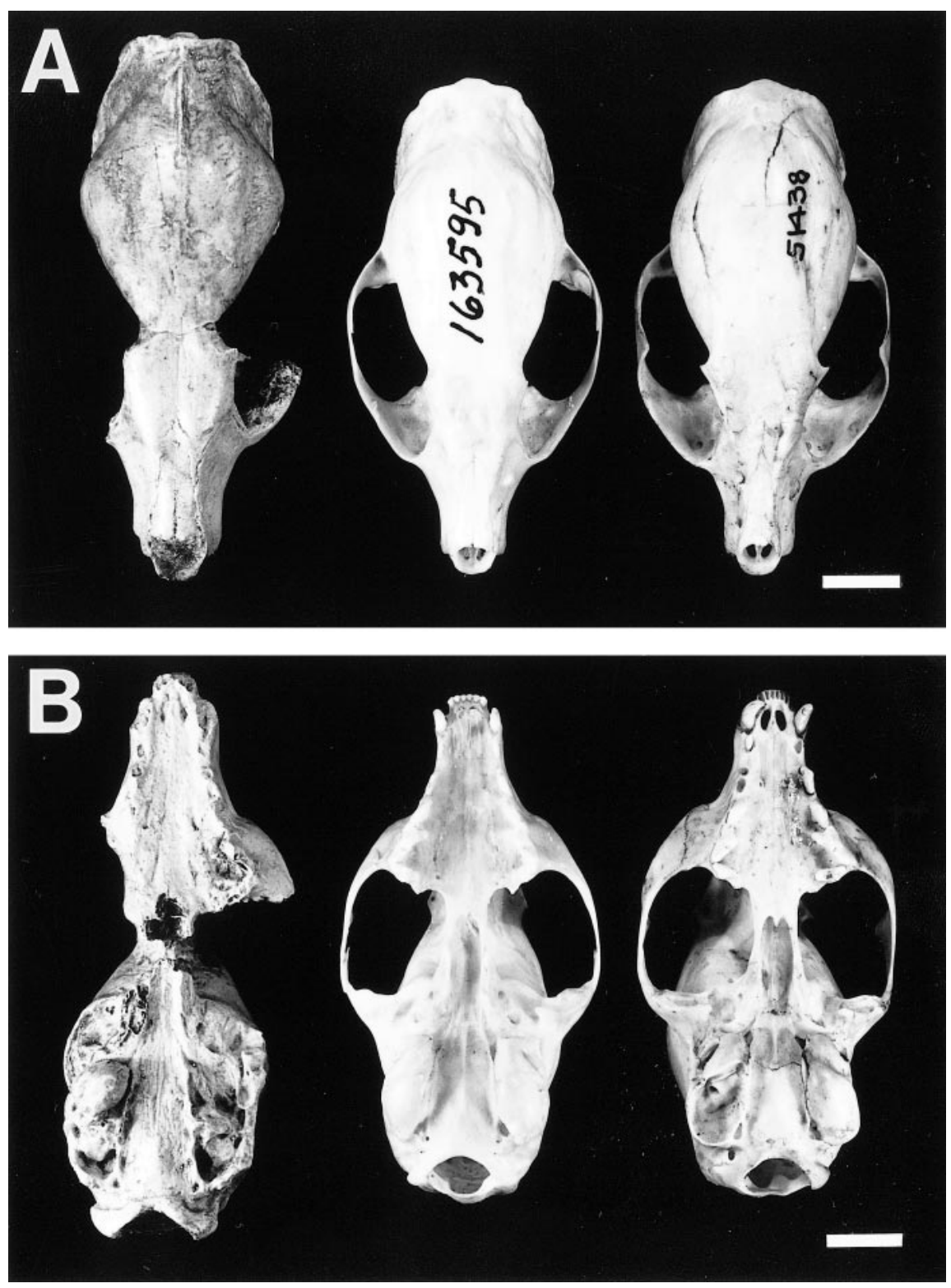

Fig. 2. Skulls of the Quercy Palaeoprionodon (MNHN Qu 9370), the Asian linsang Prionodon pardicolor (AMNH 163595), and the African linsang Poiana richardsoni (AMNH 51438), from left to right. (A) dorsal view; (B) ventral view. Scale bar in this and all subsequent figures is $1 \mathrm{~cm}$.

shape and size and are arranged in a transverse row (I3 is only slightly larger than the interior incisors). P1-3 are thin bladelike teeth; Prionodon still retains a plesiomorphic double-rooted P1, whereas P1 in Poiana and Genetta is single-rooted. P4 is a typical shearing carnassial with a small cuspate pro- tocone and diminutive parastyle. The M1 is not present in the Palaeoprionodon skulls but, based on placement of the alveoli, probably was similar in form to M1 in the linsangs where this tooth is a small narrow triangle with a prominent parastyle. However, M1 in Prionodon retains a distinct paracone 

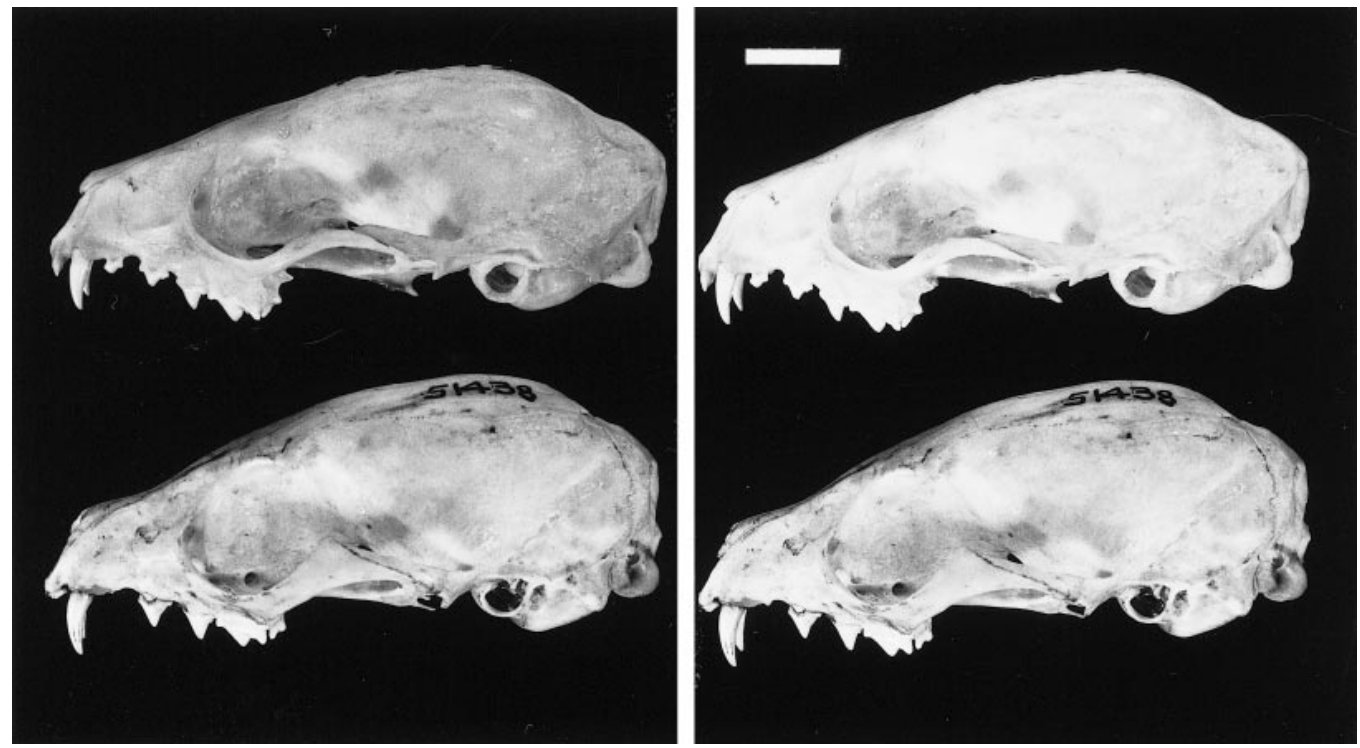

Fig. 3. Skulls of the Asian linsang Prionodon pardicolor (AMNH 163595, above) and African linsang Poiana richardsoni (AMNH 51438, below) in lateral view. Figures 3-10 are stereophotographs.

and metacone and is not as narrow as in Poiana, in which the paracone-metacone are subsumed in a thin crest and are no longer distinct cusps. I have not observed M2 in any of the living linsangs, but a vestigial M2 occurs in some individuals of Palaeoprionodon, and M2 has been reported in some specimens of Poiana richardsoni (Ewer, 1973; Rosevear, 1974). In the linsangs, the palatal choanae are closed (floored by bone) for 4$5 \mathrm{~mm}$ posterior to the M1s, whereas in $\mathrm{Pa}$ laeoprionodon this closure is not present.

In the mandible, the premolars (p2-4) of the living linsangs are thin bladelike teeth, each with anterior and posterior cingulum cusps and a posterior accessory cusp; in the Quercy genus the form of p3-4 is like that of the linsangs, but the $\mathrm{p} 2$ is usually reduced in size and thus often lacks these additional cusps. Remarkably, Prionodon shows the same reduction in size of $\mathrm{p} 2$ (relative to $\mathrm{p} 3$ ) seen in Palaeoprionodon, but the reduced p2 does not occur in Poiana. The p2 of Poiana is tall, not low, and in this trait, and in the form of the entire premolar row, it is clearly like that of the genets. The $\mathrm{p} 1$ is double-rooted in Prionodon but is reduced to a singlerooted tooth in Poiana and Genetta.

There is a very close correspondence of $\mathrm{m} 1$ form in Prionodon and Palaeopriono- don: both have a tall trigonid with the paraconid-protoconid shearing blade set apart from a well-developed, conical, posterolingually directed metaconid, accompanied by a reduced, low, slightly basined talonid. But an even more striking similarity exists in the form of $\mathrm{m} 2$ in these two genera. The $\mathrm{m} 2$ of the Quercy genus is distinguished by a small low trigonid, in which the metaconid is set well apart (posterolingually displaced) from the protoconid-paraconid and separated from them by a prominent valley (Hunt, 1998: fig. $6 \mathrm{~h})$. This same derived form of $\mathrm{m} 2$ occurs in Prionodon pardicolor, but in the single individual of Poiana richardsoni that I was able to examine, the $\mathrm{m} 2$ trigonid lacks the strongly displaced metaconid, and has the three trigonid cusps closely grouped as the points of an equilateral triangle. Neither $\mathrm{Pa}$ laeoprionodon nor the species of living linsangs retain an $\mathrm{m} 3$.

Among the living viverrids, the taxa most closely resembling the linsangs in dentition, body form, and pelage are the genets $(\mathrm{Ge}$ netta genetta and related species, Kingdon, 1977). Genets appear to be African linsangs scaled to larger size, differing only in such minor features as retention of M2 and in subtle variation in pelage patterns.

Thus, initial comparison of cranial and 
TABLE 1

Comparative Cranial Measurements (in mm) of Prionodon pardicolor, Palaeoprionodon lamandini, and Poiana richardsoni (Carnivora, Viverridae).

\begin{tabular}{|c|c|c|c|c|}
\hline \multirow[b]{3}{*}{ Measurement } & \multicolumn{4}{|c|}{ TAXON } \\
\hline & \multirow{2}{*}{$\begin{array}{c}\text { Prionodon } \\
\text { pardicolor } \\
\text { AMNH } 163595\end{array}$} & \multicolumn{2}{|c|}{ Paleoprionodon lamandini } & \multirow{2}{*}{$\begin{array}{c}\text { Poiana } \\
\text { richardsoni } \\
\text { AMNH 51438 }\end{array}$} \\
\hline & & Qu 9348 & Qu 9370 & \\
\hline Basilar length & 60.2 & 67.4 & 71.7 & 61.2 \\
\hline Rostral width ${ }^{a}$ & 13.8 & 14.8 & 14.9 & 12.0 \\
\hline Braincase, greatest width & 24.1 & 26.9 & 27.8 & 24.7 \\
\hline Palatal width between P4 paracones & 12.7 & 14.7 & $16.5^{b}$ & 11.8 \\
\hline Width between postorbital processes & 13.8 & 13.1 & 15.3 & 16.8 \\
\hline Width between mastoid processes & 21.8 & 24.6 & 24.9 & 21.4 \\
\hline Width between condyloid foramina & 8.7 & 9.6 & 10.1 & $9.1^{c}$ \\
\hline Ectotympanic, length & 6.8 & 8.8 & 8.9 & 6.6 \\
\hline Ectotympanic, width at center & 3.1 & 4.6 & 4.9 & 3.9 \\
\hline Length, anterior auditory region ${ }^{d}$ & 5.9 & 8.1 & 8.2 & 5.6 \\
\hline Length, posterior auditory region ${ }^{e}$ & 7.0 & 6.6 & 6.9 & 9.2 \\
\hline Condylobasal length & 64.3 & 70.0 & 74.1 & 65.2 \\
\hline Condylobasal length $f$ & $\begin{array}{l}68.0 \\
71.3 \\
67.6\end{array}$ & \multicolumn{2}{|c|}{$\begin{array}{l}\text { (Prionodon pardicolor, } \mathrm{N}=7 \text { ) } \\
\text { (Prionodon linsang, } \mathrm{N}=9 \text { ) } \\
\text { (Poiana richardsoni, } \mathrm{N}=7 \text { ) }\end{array}$} & \\
\hline $\begin{array}{l}{ }^{a} \text { Measured between infraorbital fo } \\
{ }^{b} \text { Estimated measurement. } \\
{ }^{c} \text { Condyloid foramina are placed w } \\
{ }^{d} \text { Measured from apex of ventral p } \\
{ }^{e} \text { Measured from the apex of the } \\
\text { chamber of the bulla. } \\
{ }^{f} \text { From Pocock (1933). } \\
{ }^{g} \text { From Rosevear (1974). }\end{array}$ & $\begin{array}{l}\text { osterior lacerate fo } \\
\text { process to anteri } \\
\text { montorial process }\end{array}$ & $\begin{array}{l}\text { oramina. } \\
\text { ior limit of ec } \\
\text { to the poster }\end{array}$ & $\begin{array}{l}\text { anic. } \\
\text { iit of the ca }\end{array}$ & dal entotympanic \\
\hline
\end{tabular}

dental anatomy of the linsangs with the Quercy fossils suggests the possibility of relationship, one in which Prionodon is most similar to Palaeoprionodon; Poiana is more derived in its morphology, showing many correspondences with Genetta-the basicranium provides particularly relevant information on the nature of this relationship.

\section{BASICRANIAL ANATOMY OF PALAEOPRIONODON}

I have been able to study the basicranial anatomy of two skulls of Palaeoprionodon lamandini from Quercy, France, in the collections of the Muséum National d'Histoire Naturelle, Paris. Both preserve the basicranium in very good condition: MNHN Qu 9348 retains both ectotympanic bones (one in the life position, demonstrated by the placement of the ectotympanic crura in sockets in the squamosal bone), and MNHN Qu
9370 preserves one ectotympanic - this bone is absent from the opposite side, allowing a full view of the petrosal and middle ear in this species. Detailed descriptions of the basicranial structure of these two skulls are presented in Hunt (1998). Here I illustrate Qu 9348 (fig. 4), and compare it with the basicrania of the living linsangs.

The hallmark of the auditory region of $\mathrm{Pa}$ laeoprionodon is a large, centrally placed, blocky petrosal, whose promontorium extends below the plane of the basioccipital to form a prominent ventral process (fig. 4, V). This process buttresses the lateral margin of the basioccipital. The apex of the promontorium with its ventral process divides the auditory region into anterior and posterior parts. The anterior part is covered by the crescent-shaped ectotympanic bone: the tip of the anterior crus rests in a small depression in the squamosal; internal to this is a 
broader concavity for the anterior face of the ectotympanic. The posterior crus is attached to the post-tympanic process of the squamosal that forms the anterior face of the mastoid process.

The petrosal promontorium is so large in these early aeluroids that the posterior limb of the inwardly tilted ectotympanic crescent makes contact with the petrosal (fig. 4C, Z). This contact is marked by a prominent facet on the surface of the promontorium, immediately lateral to the ventral process (fig. 4B, F). This distinctive juxtaposition of ectotympanic against the robust petrosal is an important anatomical characteristic of the genus.

However, it is the posterior part of the auditory region behind the promontorium that displays a striking plesiomorphic morphology unique to Palaeoprionodon among fossil aeluroids. Many living aeluroids (particularly felids and viverrids) have a greatly lengthened auditory region behind the promontorium, and this elongated space is occupied by a markedly inflated bony entotympanic capsule, the caudal entotympanic of Van der Klaauw (1922). In contrast, the earliestknown aeluroid crania from Quercy (Palaeoprionodon, Stenoplesictis) and St.-Gérand (Stenogale) have short posterior auditory regions of very small volume, which would have been covered by a small, uninflated caudal entotympanic (Hunt, 1998). It is true that in the fossil Quercy crania no ossified caudal entotympanic element has been preserved that would establish its actual size and shape. However, although the posterior auditory region remains open and uncovered in these Quercy aeluroids, the rim of the ectotympanic and the surfaces of the petrosal and surrounding basicranial bones demonstrate conclusively that a small plesiomorphic caudal entotympanic was present (fig. 4B, $\mathrm{x}$ and black triangles). It was either too loosely attached to remain with the skull during fossilization or was formed of an unossified connective tissue, such as cartilage, which decayed and was not preserved.

Among the living aeluroids, only the African palm civet, Nandinia binotata, retains a cartilaginous caudal entotympanic in the adult (fig. 5). This is the most plesiomorphic caudal entotympanic known among living aeluroids (Hunt, 1987: 32): a small, uninflated hyaline cartilage that encloses a posterior auditory space of very small volume. When Nandinia's caudal entotympanic is removed from the auditory region, its perimeter of attachment to the ectotympanic, petrosal, and rostral entotympanic is marked by characteristic ridges and rugose surfaces. Because the areas for the attachment of the caudal entotympanic to the ectotympanic and petrosal in Palaeoprionodon are nearly identical to the same areas in Nandinia (compare figs. 4 and $5 \mathrm{~A}$ ), it is virtually certain that a connective tissue element of similar form and dimensions, either fibrous or cartilaginous, formed the caudal entotympanic in Palaeoprionodon. This presumably cartilaginous entotympanic would have covered the posterior auditory region, forming its floor, and then, as in young Nandinia, extended forward as a strip of tissue along the medial rim of the ectotympanic (fig. 5B, C). In both Nandinia and Palaeoprionodon there is a gap between the inner margin of the ectotympanic and the rostral entotympanic. This strip of connective tissue would fill this gap, intervening between the inner edge of the ectotympanic and the ventral edge of the rostral entotympanic (compare figs. 4B, C and 5B, C); the rostral entotympanic is preserved as a small osseous wedge, separated from the ectotympanic, in some Quercy Palaeoprionodon (fig. 4, R). This condition can be observed in both juveniles and young adults of Nandinia (fig. 5, R).

Thus, the auditory bulla of Palaeoprionodon was made up of three ontogenetic elements: (a) a small, wedge-shaped, osseous rostral entotympanic in the anterointernal corner of the auditory region; (b) a slightly inflated (widened) bony ectotympanic crescent applied to the surface of the petrosal; and (c) a fibrous or cartilaginous caudal entotympanic element of small size, covering a posterior auditory area of very small volume. Palaeoprionodon exhibits a plesiomorphic aeluroid auditory cachet, identified by the form of the petrosal and its ventral process, the ectotympanic resting against the robust promontorium, and particularly by the modest volume of the posterior chamber of the bulla enclosed by an unexpanded and unossified caudal entotympanic. 

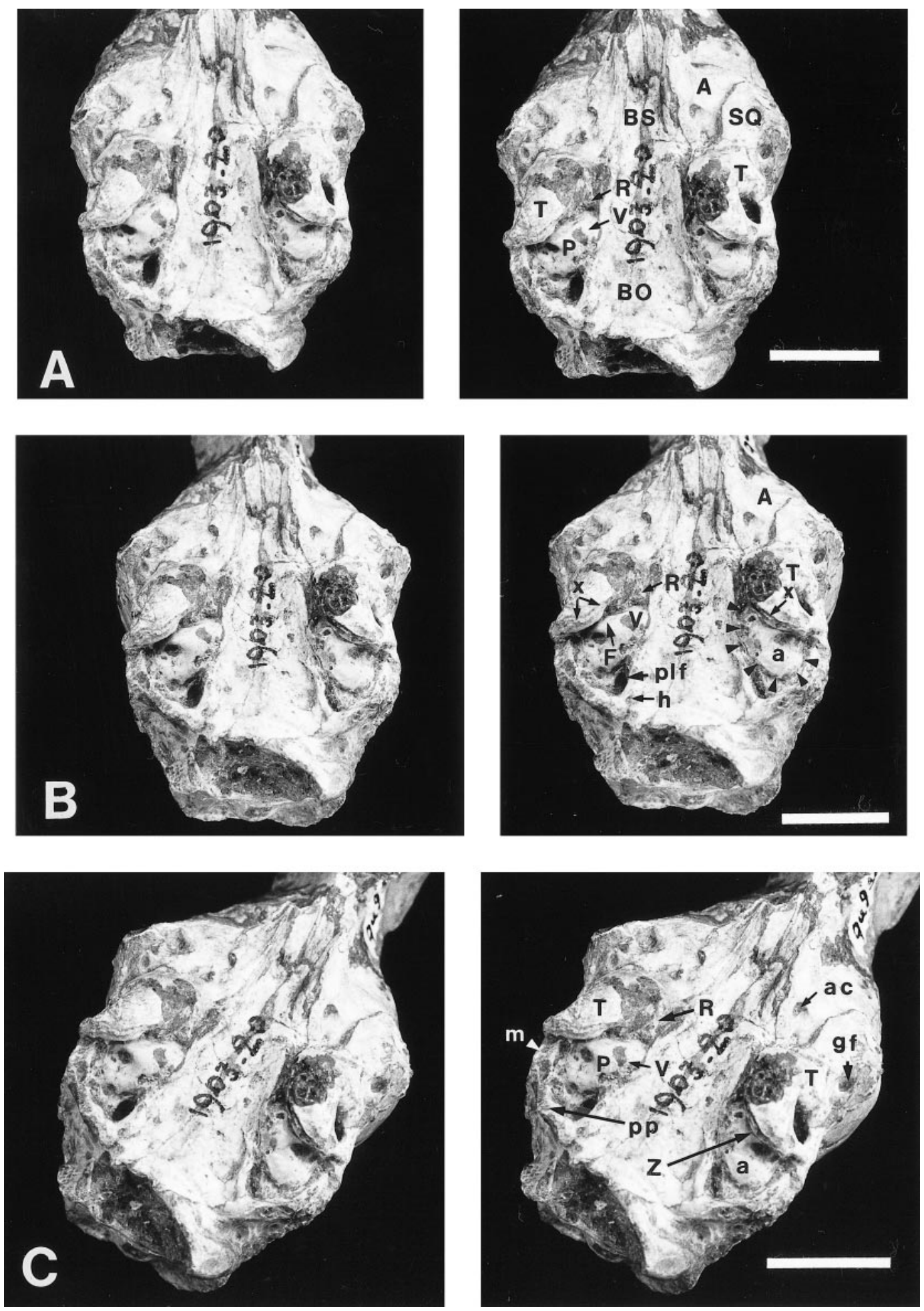

Fig. 4. The basicranium of Palaeoprionodon (MNHN Qu 9348) from Quercy: (A) ventral, (B) posteroventral, and (C) posterolateral views. In (B) small black triangles indicate line of attachment of the caudal entotympanic to the margin of the petrosal. For abbreviations in this and subsequent figures, see pages 3-4. 

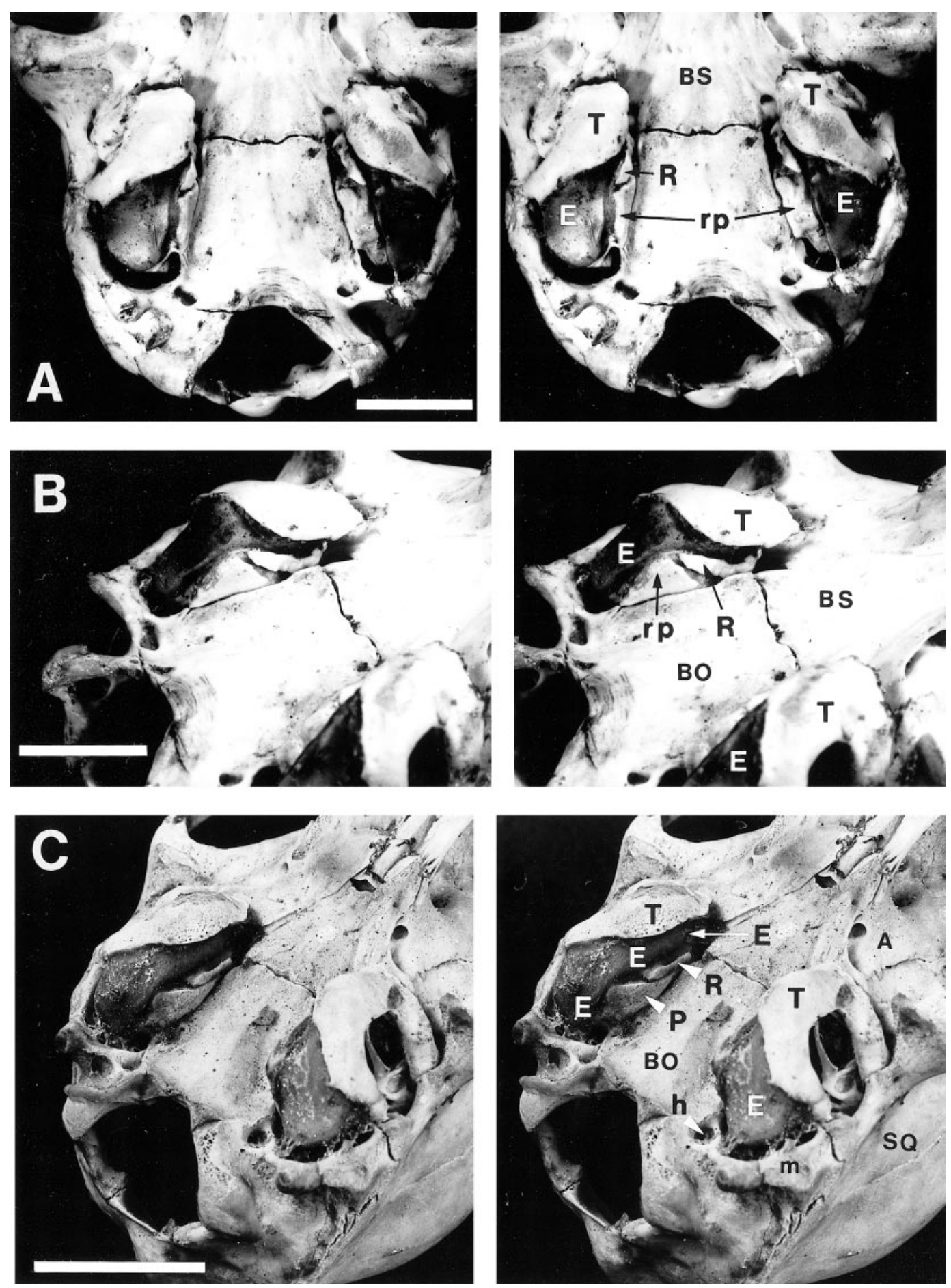

Fig. 5. Basicranium and auditory region of the living African aeluroid Nandinia binotata. (A), juvenile female from Akenge, Zaire (AMNH 51450), ventral view; (B) medial view of AMNH 51450; (C) neonate, from Medje, Zaire (AMNH 51472). The ectotympanic is separated from the osseous rostral entotympanic by an intervening strip of connective tissue representing the anterior continuation of the caudal entotympanic. 


\section{BASICRANIAL ANATOMY OF PRIONODON AND POIANA}

A skull of Prionodon pardicolor was made available for dissection by the Department of Mammalogy, American Museum of Natural History. It is a female collected in 1938 from Mt. Victoria, Chin Hills, Burma, at an elevation of $2800 \mathrm{~m}$ (AMNH 163595). The form and size of the skull and the expression of many anatomical details are extremely similar to those of the Quercy $\mathrm{Pa}$ laeoprionodon, and this is reflected in the generic name initially given to the fossil taxon by Filhol (1880: 1579). Previous studies have emphasized the anatomical similarities between Prionodon and Palaeoprionodon (Teilhard de Chardin, 1915; Gregory and Hellman, 1939), but did not include a comparison of their basicranial anatomy. Although relevant distinctions can be found between the two genera, the basicranial anatomical pattern of the living Prionodon pardicolor, including construction of the auditory bulla, shows an evident relationship to the pattern in Palaeoprionodon.

For comparison with the Asian linsang Prionodon, a skull of the African linsang, Poiana richardsoni, was also made available for study - its auditory bulla already partially dissected. It is a male collected in 1910 from Medje, Zaire (AMNH 51438), at an unknown elevation in the northeastern part of the west African rain forest (Allen, 1924).

Figure 6 compares the basicrania of the Asian linsang (Prionodon pardicolor, AMNH 163595) and the African linsang (Poiana richardsoni, AMNH 51438). In general the two linsangs share a similar anatomical pattern. Some differences are evident: (a) the condyloid (hypoglossal) foramen remains separate from the posterior lacerate foramen in Prionodon, but is incorporated in that foramen in Poiana; and (b) the ossified caudal entotympanic element of the auditory bulla is more inflated in Poiana than in Prionodon, and in the former has grown forward over the ectotympanic and backward toward the paroccipital process to a greater degree than seen in Prionodon. In both of these characters, Prionodon is the more plesiomorphic taxon.

In both genera there is an alisphenoid ca- nal; a postglenoid foramen is absent, indicating loss of the vein exiting the cranium at that point to supply the external jugular venous drainage (which is present in Palaeoprionodon); the form and placement of the glenoid fossa for the mandible and its relation to the auditory bulla and foramen ovale is the same; the mastoid region is not developed as a prominent process or shelf; the ectotympanic (anterior) chamber of the bulla lies directly in front of the caudal entotympanic (posterior) chamber; and the ectotympanic bone is a slightly expanded element resting on the petrosal promontorium.

Pocock (1916b) and Bugge (1978) described the path of the internal carotid artery in the auditory region of a number of viverrids but did not include the linsangs. The internal carotid artery in both genera takes essentially the same course: it enters the auditory region about midway along the length of the bulla-the point of entrance can be observed at the posterior end of the ventral process of the promontorium (fig. 6). The artery runs between the flanged ventral process and the caudal entotympanic (remaining external to that element, hence extrabullar), next travels along the lateral surface of the ventral process, and then follows the ventral edge of the rostral entotympanic, turning medially to enter the cranial cavity at the middle lacerate foramen. It is partially or entirely enclosed in a bony tube along the ventral border of the rostral entotympanic. (Pocock [1916b] mistakenly thought that the rostral entotympanic of viverrids was part of the ectotympanic bone.) The anteriorly directed artery makes an abrupt $180^{\circ}$ change in course at its anterior terminus in the auditory region-here the artery forms a loop nested in a depression in the basisphenoid, turning backward to enter the middle lacerate foramen. Thus, during its passage through the auditory region, the internal carotid artery never takes an intrabullar course: the artery does not penetrate the caudal entotympanic element to enter the posterior chamber of the bulla, and because it remains confined to the edge of the rostral entotympanic, it does not enter the anterior bulla chamber.

Prionodon has a robust, blocky petrosal centrally situated in the auditory region (fig. 7). Its promontorium is elevated to form a 

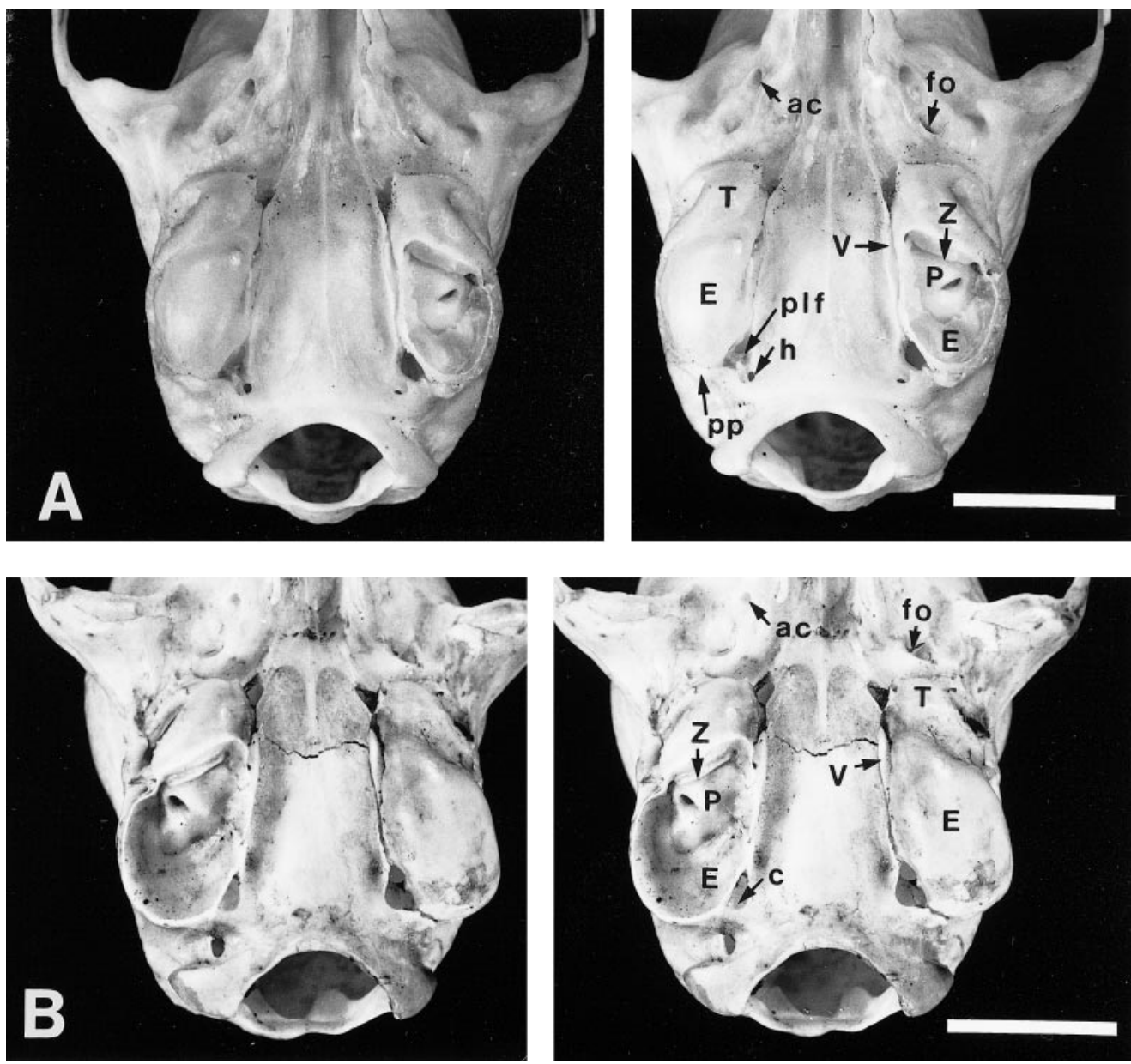

Fig. 6. Basicrania of Prionodon (AMNH 163595, A) and Poiana (AMNH 51438, B) in ventral view. The bony floor of the posterior chamber of the auditory bulla has been removed on one side in each individual to show the ectotympanic resting on the petrosal promontorium, and the size of the posterior chamber formed by the caudal entotympanic. Note the more expanded or inflated posterior chamber in Poiana relative to Prionodon.

well-developed ventral process (V) that buttresses the edge of the basioccipital (fig. 7B). The margins of the basioccipital are bent downward and applied to the medial face of the petrosal. Although the posterior face of the promontorium is more smoothly rounded in the Asian linsang, the form of the Prionodon petrosal is much like that of Palaeoprionodon. However, in Prionodon, the ventral process of the promontorium has a somewhat more derived appearance than seen in the Quercy genus: it is apparent that the living Asian linsang has modified the blocky ventral process of Palaeoprionodon, reshaping it into a low, laterally compressed flange tightly applied to the basioccipital. This flange becomes even more prominently developed and bladelike in other genera of living viverrids (e.g., Genetta, Civettictis), but remains in an incipient state in Prionodon. In Poiana the promontorium and the flange are similar to these features in Prionodon, but the condition of the flange in Poiana is slightly more derived and begins to approach the more developed petrosal flange observed in such living viverrids as Genetta. 

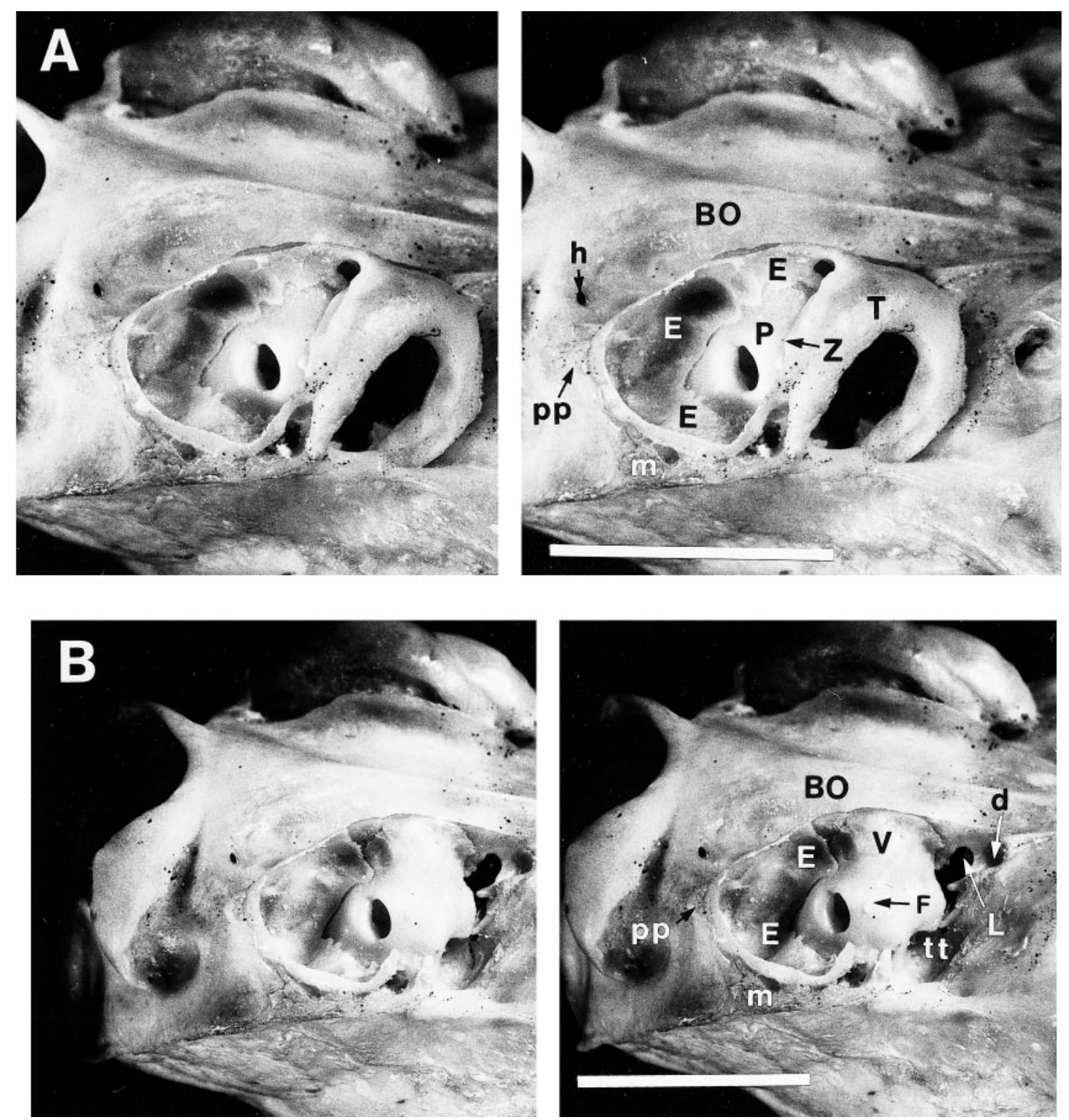

Fig. 7. Dissection of the auditory region of Prionodon pardicolor (AMNH 163595) in oblique lateral view. The posterior chamber of the bulla has been opened (A), revealing the inflected dorsal margin of the caudal entotympanic applied to the petrosal, and the ectotympanic resting on the promontorium anterior to the round window. Removal of the ectotympanic and rostral entotympanic (B) allows an unrestricted view of the petrosal promontorium with its robust ventral process forming an incipient flange buttressing the edge of the basioccipital. Note that the caudal entotympanic covers the ventral process of the promontorium when in place.

The degree of thinning of the ventral process of the petrosal in living viverrids (resulting in the eventual development of the bladelike flange) is an index of the amount of caudal entotympanic expansion. As the auditory bulla of viverrids evolved, the posterior chamber increased in volume by expansion of the caudal entotympanic element. During this process of relative growth, application of the enlarging caudal entotym- 
panic to the petrosal promontorium altered the form of the ventral process in both Prionodon and Poiana.

In the Quercy aeluroid, Palaeoprionodon, the unossified caudal entotympanic was similar in form to the cartilaginous entotympanic of Nandinia (fig. 5; also Hunt, 1987: figs. 6, 7B, 15-16), based upon a comparison of the well-preserved auditory anatomy of MNHN Qu 9348 and 9370 with that of Nandinia. The caudal entotympanic was a small, unexpanded element that covered the posterior auditory region behind the ectotympanic. Although it extended anteriorly along the medial rim of the ectotympanic to form part of the medial wall of the bulla, it did not alter the form of the ventral process of the promontorium. But in Prionodon, the anteriorly migrating and enlarging caudal entotympanic, accompanied by ossification of the element, compressed the ventral process to create the incipient flange. Continued enlargement and anterior growth of the caudal entotympanic chamber eventually produced the more derived flange observed in Poiana and in other living viverrids. The conversion of the ventral process of the promontorium in Poiana into an incipient flange proceeds from the posterior part of the process forward, and the creation of the flange is caused by the margin of the caudal entotympanic element pressing only into the posterior part of the process, while not advancing craniad. This demonstrates that an advancing caudal entotympanic element can produce such a flange as it enlarges by a process of relative growth.

It is interesting that in a juvenile Poiana richardsoni (AMNH 51440) the ectotympanic is even larger in proportion to the caudal entotympanic than in the adult, and the relative size of these two bulla elements in this juvenile effectively duplicates the size of the ectotympanic and (hypothetical) caudal entotympanic elements in Palaeoprionodon. AMNH 51440 also shows that the caudal entotympanic in a juvenile is confined to the posterior auditory region behind the ventral process of the promontorium and has not initiated any significant forward growth in order to cover the ectotympanic. This is also true of Prionodon pardicolor.

The Asian linsang Prionodon and the
Quercy Palaeoprionodon share a similarly shaped ectotympanic bone, inclined inward toward the midline to the same degree, and resting on the promontorium. The posterior limb of the ectotympanic is directly applied to the surface of the promontorium immediately anterior to the round window. Contact is made over a linear distance of $\sim 3-4 \mathrm{~mm}$ in Prionodon (fig. 6, Z), but in the Quercy carnivore the contact is restricted to the lateral part of the promontorium at the location of the facet (fig. 4, Z). In Prionodon this contact extends farther medially, creating a more complete partition between the anterior and posterior chambers of the bulla. Both Poiana and Prionodon share this more internally extended application of the ectotympanic rim to the promontorium (fig. 6, Z), which seems to be a derived trait, whereas the condition in the Quercy genus is considered to represent the initial (rudimentary) application of the ectotympanic to the petrosal. Also, the ectotympanic in Prionodon is relatively and absolutely smaller than in Palaeoprionodon (table 1), so that in the Quercy genus the large ectotympanic and massive petrosal combine to produce an anterior bulla chamber of somewhat greater volume relative to the Asian linsang.

Just as in the Quercy genus, a small, wedge-shaped bony rostral entotympanic fits tightly into the anterointernal corner of the auditory region in Prionodon. Along its ventral margin runs the internal carotid artery, enclosed in a bony tube, with the exception of a short section of the lateral wall of the tube that is not ossified and is closed by connective tissue. The medial rim of the ectotympanic is inflected, and contacts and fuses with the edge of the rostral entotympanic.

The Asian and African linsangs share the same form and spatial relationship of the ectotympanic and rostral entotympanic. In both genera the inner margin of the ectotympanic contacts the ventral edge of the rostral entotympanic. The two bulla elements fuse along this line without intervention of the caudal entotympanic, and when the ectotympanic is carefully detached from the auditory region, the rostral entotympanic accompanies it, the two elements delicately attached along the inner rim of the ectotympanic bone (fig. 8). In both genera, the internal carotid artery 

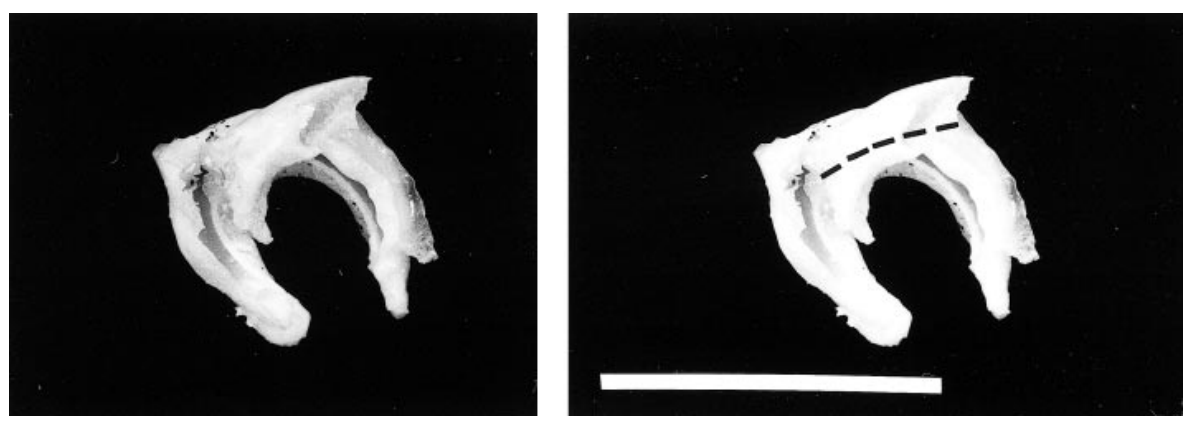

Fig. 8. Rostral entotympanic fused to the inner margin of the ectotympanic in Prionodon (AMNH 163595), medial view, ventral at top. Dashed line indicates path of the internal carotid artery within the ventral edge of the rostral entotympanic.

travels along the ventral edge of the rostral element and does not enter the middle ear cavity. The application of the relatively unexpanded ectotympanic to the small rostral entotympanic element in Prionodon and Poiana is an aeluroid character state also present in most other living viverrids, hence does not distinguish these genera.

The American Museum skulls of the Asian and African linsangs can be immediately separated by the different degree of expansion of the caudal entotympanic. Among all living viverrids, Prionodon pardicolor shows the closest correspondence to Palaeoprionodon in the small volume of its posterior bulla chamber (fig. 7). Measurements of the length of the posterior auditory region (table 1 ) indicate that $P$. pardicolor is proportionately similar to the Quercy genus, and differs in this regard from Poiana (fig. 9). There is less expansion or inflation of the caudal entotympanic in Prionodon relative to Poiana, and during the ontogeny of these linsangs a progressive increase in inflation of this element occurs (e.g., a juvenile of Poiana richardsoni, AMNH 51440, a male with milk teeth collected in 1914 at Niapu, Zaire, shows less inflation of the caudal entotympanic than in the adults).

In Prionodon the relative amount of caudal entotympanic inflation appears to increase from northwest to southeast over the geographic range of the genus. Skulls of Prionodon pardicolor from Sikkim (FMNH 35463, female; 35464, male) at the northwestern geographic limit of the species display the least inflation. Skulls of $P$. pardi- color from Tonkin and Assam (FMNH $39175,39176,75814$, all males) show an intermediate degree of inflation. Skulls of Prionodon linsang from Borneo (FMNH 88606 , male; 8371 , female) at the southeastern limit of the genus in southeast Asia develop the most inflated caudal entotympanic chambers. Inspection of Prionodon linsang in other North American collections indicates that this species has a consistently more inflated caudal entotympanic bulla than $P$. pardicolor. In $P$. linsang the caudal entotympanic has grown forward, nearly covering the medial border of the ectotympanic, whereas in $P$. pardicolor the caudal entotympanic remains largely posterior to the ectotympanic, migrating forward along its posterointernal margin in slight but varying degree in different individuals.

An estimate of the relative amount of caudal entotympanic inflation in Prionodon and Poiana is further indicated by the relationship of the paroccipital process to the posterior wall of the caudal entotympanic. In plesiomorphic carnivorans (e.g., Nandinia, Daphoenus, Cynodictis, Amphicynodon, Mustelictis, nimravine cats), the paroccipital process is not applied to the bulla, but rather exists as a rodlike process diverging posteroventrally from the exoccipital. In most living viverrids, including Poiana, posterior growth and expansion of the caudal entotympanic creates a firm contact between entotympanic and the paroccipital process of the exoccipital, and as a result the process has become broadened and dorsoventrally expanded into a thin sheet of bone that covers most of the 

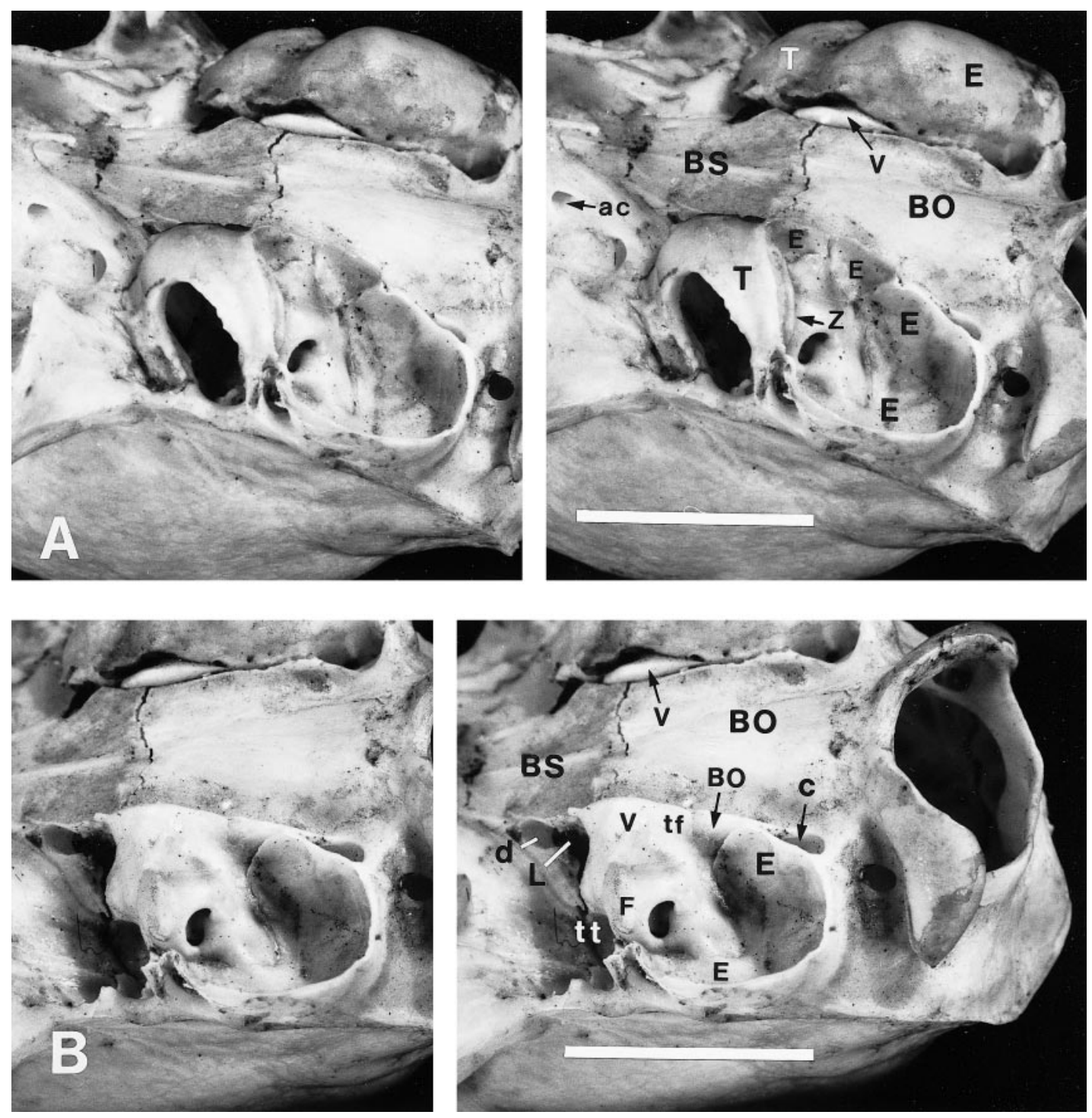

Fig. 9. Dissection of the auditory region of Poiana richardsoni (AMNH 51438) in oblique lateral view (compare with fig. 7). The posterior chamber of the bulla has been opened (A), showing the inflected dorsal margin of the caudal entotympanic applied to the petrosal, and the ectotympanic resting on the promontorium anterior to the round window. Removal of the ectotympanic and rostral entotympanic (B) reveals the petrosal promontorium with ventral process produced as a flange buttressing the edge of the basioccipital. The flange is more developed in Poiana than in Prionodon, and the caudal entotympanic element is more inflated.

posterior bulla wall. A discrete rodlike paroccipital process no longer exists in these viverrids. But in Prionodon, only a minimal amount of posterior expansion of the posterior bulla chamber (formed by caudal entotympanic) has taken place, and there is mere- ly a rudimentary contact between the bulla and the base of the paroccipital process. Consequently, the base of the process is only weakly indented by the expanding bulla, and the tip of the process remains recognizable, diverging slightly ventrad from the bulla (Po- 
cock, 1933). In primitive aeluroids, such as Palaeoprionodon and the living palm civet, Nandinia, the unossified caudal entotympanic attaches near the base of the paroccipital process, and the process remains a rodlike structure, descending from the skull, and is not thinned and applied to the bulla wall.

According to this interpretation, Prionodon is arrested at an evolutionary stage of bulla development only somewhat more advanced than Palaeoprionodon, and evidently derived from that stage. The principal morphological changes necessary to modify the bulla of the Quercy aeluroid to arrive at the bulla morphology of Prionodon involved ossification of the caudal entotympanic that forms the posterior chamber of the bulla, accompanied by a small amount of inflation of the chamber. The modest inflation of the caudal entotympanic in Prionodon resulted in a slight change in shape of the ventral process of the promontorium, creating a nascent configuration of the petrosal flange that became more prominently modified and developed in other living viverrids. The auditory anatomy seen in Prionodon can be explained as an intermediate morph between the character state found in Palaeoprionodon and that of Poiana.

\section{DISCUSSION AND CONCLUSIONS}

The basicranial anatomy of the Asian linsang, Prionodon pardicolor, is of particular significance in a consideration of the early evolution of aeluroid carnivorans. Previously, a study of the oldest known fossil aeluroids from Quercy and St.-Gérand (Palaeoprionodon, Stenoplesictis, Stenogale, Haplogale, Anictis) indicated the existence of a primitive morphology of the petrosal and auditory bulla common to several of these early aeluroid taxa (Hunt, 1998). Skulls with wellpreserved basicrania are known for Palaeoprionodon, Stenoplesictis, and Stenogale. The auditory regions of these fossil aeluroids compare in anatomical grade with the living archaic aeluroid, Nandinia binotata, but no connecting or intermediate morphological stage existed to link the archaic and the modern basicranial types. The basicranium of Prionodon pardicolor, particularly the auditory bulla and petrosal, provides that critical link. Its auditory region not only can be derived from that of the Oligocene aeluroid, Palaeoprionodon, but also can be interpreted as a transitional state between the Quercy genus and the living African linsang, Poiana. Both Prionodon and Poiana exhibit an early stage in the development of the modern viverrid auditory region found in living $\mathrm{Ge}$ netta, which is similar to the auditory region of the other living viverrids.

Of particular importance is the form of the petrosal promontorium in Prionodon pardicolor and Poiana richardsoni (fig. 10): the ventral process of the promontorium is produced as an incipient flange on the medial margin of the Prionodon petrosal. Poiana displays a similar but more developed flange. Yet both petrosals are very little modified from the plesiomorphic aeluroid state found in the Quercy Palaeoprionodon. Other anatomical features of the auditory region of these two living genera are correlated with the differing degree of development of the flanged ventral process-plesiomorphic characters in Asian Prionodon are consistently more derived in African Poiana: Prionodon pardicolor has (a) a modest inflation of the caudal entotympanic chamber of the bulla; (b) a discrete hypoglossal foramen separated from the posterior lacerate foramen; and (c) an independent paroccipital process-Poiana has a more developed petrosal flange, a more inflated caudal entotympanic, and has merged the hypoglossal with the posterior lacerate foramen. The greater amount of expansion of the caudal entotympanic in Poiana has caused the paroccipital process to spread over the rear wall of the bulla, but in Prionodon, because there is less expansion of the bulla, a vestige of the independent process remains.

There are other anatomical traits that suggest linsangs conserve a number of plesiomorphic viverrid features. Prionodon is more conservative in these features relative to Poiana.

For example, the surface of the neocortex of Prionodon and Poiana retains one of the simplest patterns among viverrids (Radinsky, 1975): there are only two major sulci, the coronolateral and suprasylvian, and in Prionodon the cerebellum shows only a minimal 
amount of overlap by the cerebrum, whereas in Poiana the amount of overlap is greater.

The perineal scent glands are absent in Prionodon pardicolor (Pocock, 1915a), but appear to be present in a rudimentary state in Poiana (Pocock, 1933: 970; Rosevear, 1974: 222). Pocock quite reasonably argued that the absence of perineal glands in such viverrids as Prionodon, Fossa, and Cryptoprocta, as well as their absence in herpestids, felids, and hyaenids, indicated that the ancestral aeluroid lacked such glands, which were later independently acquired in various viverrid lines. Pocock's argument receives support from the observation that perineal glands differ in position and in anatomical detail in the various living viverrids that have these glands (the details of glandular structure and position are presented in a series of papers by Pocock, 1915a, 1915b, 1915c, 1915d, 1915e; Pocock, 1915d, clearly presents his rationale for the evolution of perineal glands.) Considering the array of plesiomorphic basicranial features in Prionodon, the absence of perineal glands is instructive. In Prionodon the placement of the penis in proximity to the scrotum, and the vulva to the anus, stands in contrast to their separation in viverrids with perineal glands, and appears to be plesiomorphic for aeluroids, since this state also occurs in felids, herpestids, and Nandinia (but not in hyaenids).

Earlier studies of the linsangs by Mivart (1882) and Pocock (1915a) established that the color and pattern of the pelage and the external anatomy of the feet and rhinarium also supported a relationship between the Asian and African species. My own observations of the pelage of the two genera are in agreement (brown with black markings, mostly spotted, with some striping on the shoulders, and rings around the tail). The ability to retract the claws is present in both genera, and the texture of the fur and their general appearance and behavior particularly reminds one of many of the small living felids.

Finally, the pronounced similarity in details of the dentition of Palaeoprionodon and Prionodon (form of $\mathrm{m} 1, \mathrm{~m} 2$, reduction of anterior premolars), and the retention of plesiomorphic double-rooted $\mathrm{P} 1 / \mathrm{p} 1$ in Priono- don, also support a close relationship between the Quercy genus and the Asian linsang.

G. G. Simpson (1945) had placed Prionodon in a tribe, Prionodontini, and Poiana in the Viverrini closely related to Genetta. Such segregation of Prionodon essentially follows Pocock's (1933) separation of the genus (as a subfamily Prionodontinae) following his discovery that perineal glands were absent in both sexes. Rosevear (1974) thought that the similarities between the Asian and African linsangs were convergent and without evidence of affinity. Here I would argue that the basicranial similarities, coupled with evident correspondence in size and form of these animals, their dental and cranial traits, and pelage and external anatomy of the feet emphasized by Pocock, suggest a phylogenetic affinity among living Asian and African linsangs and genets, an affinity shared at more basic level with the archaic aeluroids of the genus Palaeoprionodon. In this sense, then, because one of these living aeluroids, Prionodon pardicolor, can be closely identified with an Oligocene genus from Quercy, and was much like it in size, body form, and in details of cranial and dental anatomy, this species of Asian linsang is reasonably considered a "living fossil", a modern proxy for an Oligocene grade of aeluroid evolution that has shown little change in $\sim 25-30$ million years.

The combined anatomical evidence suggests the existence of a clade that includes the Oligocene Palaeoprionodon as a plesiomorphic stem taxon, and the more derived living genera, Prionodon, Poiana, and Genetta, as member taxa of a hypothetical morphocline. Gregory and Hellman (1939) placed both Prionodon and Palaeoprionodon in their subfamily Prionodontinae, and this subfamily I believe can reasonably incorporate not only the Quercy Palaeoprionodon, but also the species of living linsangs and genets (table 2). Gregory and Hellman (1939: 335) thought that the skull of Palaeoprionodon could represent the ancestor "of all the diverse subfamilies of the Viverridae". Study of the Quercy fossils suggests a more limited role for Palaeoprionodon near the ancestry of only the linsangs and genets. The viverrine viverrids (Viverra, Viverricula, 

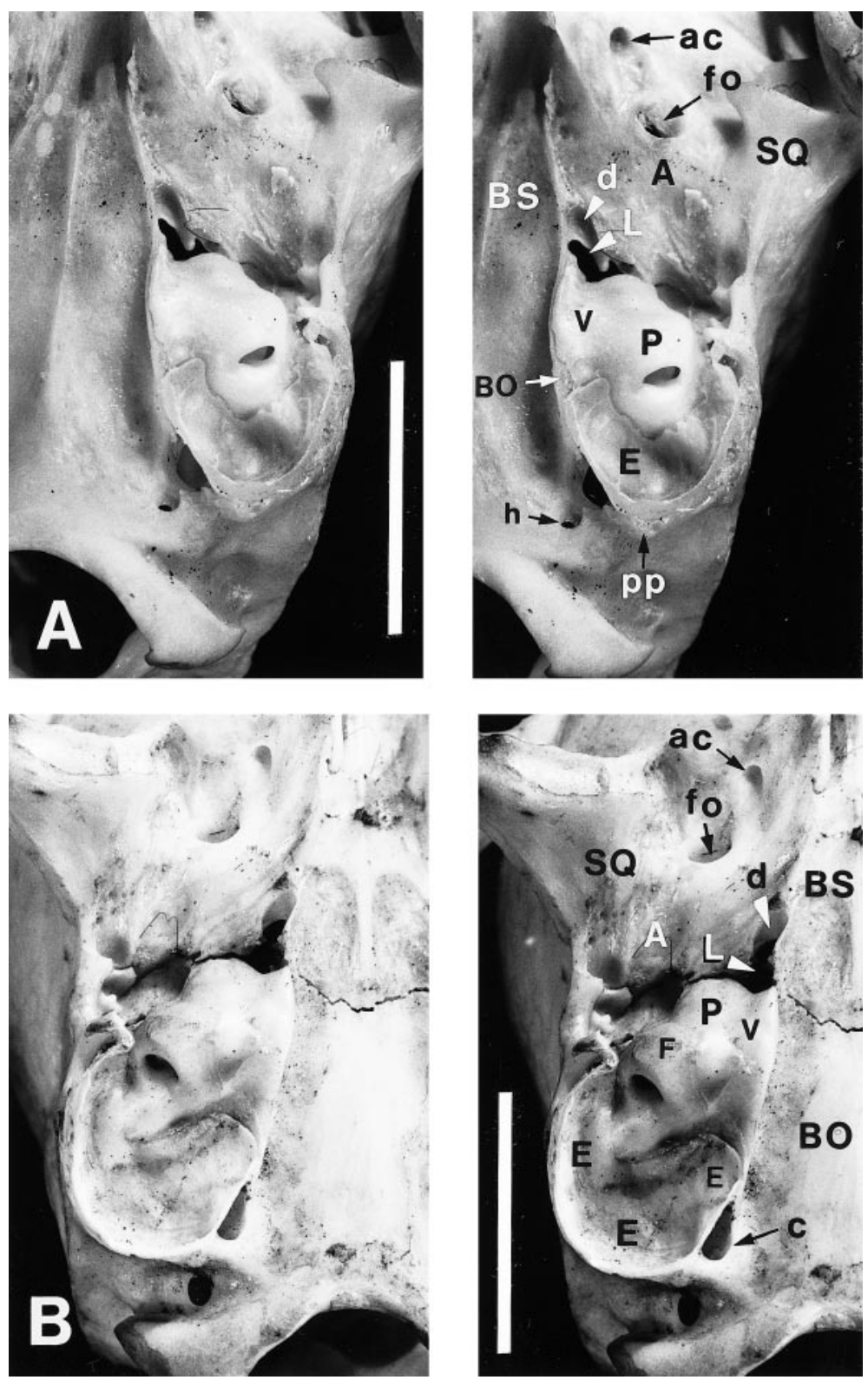

Fig. 10. Final stage of the dissection of the auditory bulla of Prionodon (AMNH 163595, A) and Poiana (AMNH 51438, B) in ventral view. Note the robust ventral process of the promontorium in Prionodon, only incipiently modified as a flange appressed against the basioccipital, hence similar to the form of the ventral process in Palaeoprionodon (compare with fig. 4). In Poiana the flange has been further modified as a thin blade and has been extended fore and aft to a greater degree than in Prionodon. The caudal entotympanic is more inflated in Poiana, broadly contacting the paroccipital process, whereas in Prionodon the caudal entotympanic is not as expanded, and the process still retains a vestige of its primitive rodlike form. 
Civettictis) appear to be closely related to the Prionodontinae because of their marked similarity in dental and basicranial anatomy. But the other principal subfamilies of viverrids, the Paradoxurinae and Hemigalinae, probably stem from other early aeluroids of Eocene or Oligocene age.

Pocock (1916b) astutely remarked that the Viverridae, as originally conceived by Flower (1869) and Mivart (1882), was "a heterogeneous group including all the aeluroids which are not obviously cats or hyaenas". Part of this heterogeneity derived from inclusion of the mongooses in Viverridae; today, herpestids have been removed from Viverridae by general consensus (Gregory and Hellman, 1939; Hunt, 1987, 1991; Wyss and Flynn, 1993; McKenna and Bell, 1997). Recent studies of the aeluroid Carnivora have recognized the morphologic uniformity of herpestids, as well as the living felids and hyaenids - a highly uniform basicranial morphology characterizes each family, and ongoing molecular/biochemical studies also support the integrity of these groups (Wurster and Benirschke, 1968; Wurster-Hill and Gray, 1975; Wayne et al., 1989). But viverrids are consistently seen as more diverse, an observation that would appear to be supported by the variety of subfamilies and genera created for these carnivores by Pocock and other students, many genera including only a single species.

Are the viverrids a monophyletic group? What evidence exists to suggest that viverrids are not simply a polyphyletic aggregate of primitive aeluroids? I would argue that three lines of evidence support monophyly: (a) the morphology of the basicranium, particularly the ontogenetic development and adult form of the auditory bulla and petrosal (Hunt, 1974, 1987); (b) the general tendency to develop perineal glands in the family (Pocock); and (c) molecular-biochemical evidence indicating relationship among genets, civets, and paradoxures (Wayne et al., 1989). But the tracing of living viverrid genera and species backward in time beyond the later Cenozoic has met with little recent success.

The relatively poor fossil record of viverrids is in part responsible for this situation (Petter, 1974; Hunt, 1996a, for a summary of the viverrid fossil record). We know little of the diversity that existed during the early history of the family, confined as it is to the Old World, where much of the viverrid record of fragmentary jaws and teeth comes from exceptional burial settings such as the fissure deposits at Quercy, La Grive, and Wintershof-West, and the freshwater limestones of St.-Gérand and Oeningen. The few European viverrid fossils, coupled with a rather meager Asian record, make it difficult to determine if the living genera are of considerable antiquity, or if the species diversity evident today in southeast Asia and Africa only recently came into existence.

Because many early viverrids were probably arboreal and thrived in subtropical to tropical forests, where skeletal remains often are infrequently preserved in the fossil record, their past history could continue to remain poorly known. However, as some viverrids occupied more open environments in semiarid to arid regions during the climatic cooling of the Neogene, particularly in tectonically active regions in south Asia and the African rift, where sedimentation in restricted basins was taking place, the probability of preservation of these species increased and a modest record has developed in these settings. But the scarcity of viverrid fossils in these sedimentary environments suggests that they were never very abundant, with a species diversity probably similar to the present.

This perspective envisions the preservation of Palaeoprionodon and other aeluroid fossils at Quercy as the chance result of the development of karst terrain in southern France in the Eocene and early Oligocene. Karst fissures serve as particularly effective traps for small carnivores. Indeed, the karst fissures at Quercy sample a rather diverse aeluroid array of taxa [the early felids Proailurus and Stenogale, a genet-like aeluroid Haplogale, the enigmatic aeluroids Stenoplesictis and Anictis (Teilhard de Chardin, 1915; Hunt, 1998)]. The Quercy "window" provides a brief, geographically limited glimpse into an aeluroid radiation that we know was not confined to western Europe but was probably unfolding throughout the Eurasian landmass, based upon the fossil aeluroid record beginning to appear at eastern Asian localities such as Hsanda-Gol, Alag 
Tsab, and Ergil Obo (Dashzeveg, 1996). Palaeoprionodon is not necessarily the ancestral viverrid, as Gregory and Hellman claimed, but is only one of a stem group of early aeluroids that includes Haplogale, Stenogale, Stenoplesictis, and Proailurus in Europe, and Asiavorator, Shandgolictis, Proailurus, and additional poorly known species in eastern Asia (Hunt, 1998). The plesiomorphic aeluroid basicranial pattern common to several of these genera suggests that the same pattern probably was shared by other early aeluroids distributed across Eurasia at this time, many as yet unrepresented by cranial remains.

The abrupt appearance of Quercy aeluroids at the beginning of the Oligocene, following the Grande Coupure event in Europe, yet their complete absence in the Eocene faunas that precede that event, has suggested to several investigators that aeluroids immigrated to Europe from elsewhere. It is possible that increasing continental aridity in central Asia during the Oligocene could have accompanied the development and radiation of aeluroids in that region, leading eventually to their spread westward across the Eurasian landmass. The importance of the fossils that we can now view through the Quercy-Mongolia "window" into early aeluroid evolution is found in the similar dentitions of these geographically dispersed fossil species, and in the uniformity of the known basicranial patterns among various genera, the sum of the evidence indicating that these aeluroid fossils document an initial phase of the Eurasian aeluroid diversification.

Of particular significance, however, is the fact that these Oligocene aeluroids do not include clear and direct morphological antecendents to modern viverrid species (with the exception of Palaeoprionodon). The Oligocene aeluroids display an archaic basicranial pattern and hypercarnivorous dentitions that are much different from the derived auditory anatomy and dentitions of many living viverrids.

Within the Viverridae, several subgroups have been consistently recognized since the 19th century (Mivart, 1882; Gregory and Hellman, 1939; Simpson, 1945; McKenna and Bell, 1997): the subfamilies Viverrinae, Paradoxurinae, and Hemigalinae (table 2).
TABLE 2

\section{Classification of the Aeluroid Families Viverridae and Nandiniidae}

Order Carnivora Bowdich, 1821

Division Aeluroidea Flower, 1869

Family Viverridae Gray, 1821

Subfamily Prionodontinae Pocock, 1933

Palaeoprionodon Filhol, 1880

Prionodon Horsfield, 1821

Poiana Gray, 1864

Genetta G. Cuvier, 1816

Subfamily Viverrinae Gray, 1821

Viverra Linnaeus, 1758

Viverricula Hodgson, 1838

Osbornictis Allen, 1919

Civettictis Pocock, 1915

Subfamily Euplerinae Chenu, 1852

Fossa Gray, 1864

Eupleres Doyere, 1835

Subfamily Cryptoproctinae Gray, 1864

Cryptoprocta Bennett, 1833

Subfamily Hemigalinae Gray, 1864

Hemigalus Jourdan, 1837

Diplogale Thomas, 1912

Chrotogale Thomas, 1912

Cynogale Gray, 1837

Subfamily Paradoxurinae Gray, 1864

Paradoxurus F. Cuvier, 1821

Paguma Gray, 1831

Arctictis Temminck, 1824

Arctogalidia Merriam, 1897

Macrogalidia Schwartz, 1910

Family Nandiniidae Pocock, 1929

Nandinia Gray, 1843

The Viverrinae most often include the genera Viverra, Viverricula, Civettictis, Osbornictis, Genetta, Poiana, and occasionally the Malagasy Fossa. All are restricted to or largely confined to Africa except for Viverra and Viverricula, which are found in southeast Asia (a large species of Viverra, however, occurred in Africa in the Plio-Pleistocene, see Petter, 1963; Hunt, 1996b). Viverrines are dentally conservative, maintaining a shearing carnassial pair and functional molars (M1-2, m1-2).

With the exception of the viverrids isolated on Madagascar (Fossa, Eupleres, Cryptoprocta; for a review see Petter, 1974), the 
remaining living genera are found in southeast Asia and the islands of Indonesia and are placed in the subfamilies Paradoxurinae (Paradoxurus, Paguma, Arctictis, Arctogalidia, Macrogalidia) and Hemigalinae (Hemigalus, Diplogale, Chrotogale, Cynogale). Certain lines of evidence, such as the endocranial casts of viverrids studied by Radinsky (1975) suggest that the paradoxures may be made up of closely related genera. Both subfamilies are composed of species that occupy forested settings; are largely nocturnal and arboreal; have perineal glands (reduced or lost in some males); are usually plantigrade, with the entire sole of the hindfoot in contact with the substrate; and have evolved modified carnassials and molars in which the typical shearing function is modified to a crushing mode, and the posterior molars can be quite small and reduced in size. Paradoxures and hemigalines seem to be geographically restricted relict species, derived from an earlier viverrid radiation in eastern Asia-an assemblage of diverse taxa that survived in tropical-subtropical settings as these environments became restricted to lower latitudes during mid- and late-Cenozoic global cooling. The climatic oscillations of the late Pliocene and Pleistocene probably contributed to the species diversity of the paradoxures and hemigalines. Lowering of global sea level during glacial maxima provided land migration routes from the Asian mainland southward to the islands of the Sunda shelf, permitting the movement of south Asian mammals into the islands of Indonesia. When warmer interglacial intervals flooded the Sunda shelf, creating the islands of Sumatra, Java, Borneo, and the numerous smaller satellite islands, the isolation of viverrid populations on these islands must have resulted in genetic fragmentation of oncecontinuous populations. With sufficient time and continued isolation, the fragmented populations could serve as a potential stockpile for the derivation of new viverrid species. The geographic restriction of paradoxures and hemigalines to forested tropical environments virtually assures that this scenario occurred in Indonesia in the later Cenozoic.

The more terrestrial viverrid species of Africa (Genetta, Civettictis) and southeast Asia (Viverra, Viverricula) are made up of con- joined or geographically adjacent populations that occur in spatial continuity over large geographic regions. The wide-ranging terrestrial character of these viverrids (although most climb well and utilize trees) suggests a genetic continuity over their ranges, with less tendency to fragment into allopatric species. Viverra-Viverricula comprises a group of similar, closely related species extending from Nepal and eastern India to south China, Indochina, and continuing southward to Malayasia and the Indonesian islands. They differ little except in size. The large bush civet, Civettictis, despite its considerable geographic range from the southern border of the Sahara southward to Namibia and South Africa, exists as a single species (C. civetta) in both forest and savanna environments. At least nine species of genets (Genetta) are said to occupy forests, grasslands, and savannas over nearly all of Africa (Nowak, 1991); this species diversity has been called into question (Rosevear, 1974), because genets are known to be highly variable in size, pelage color, and even cranial characters (Allen, 1924). It is likely that a number of the named species may in fact be capable of interbreeding and are not reproductively isolated. Much of the variation observed among the genets may be the result of the widespread distribution of the species over the African continent, and the consequent adaptation of populations to local conditions. Kingdon (1977) notes that diversification in African genets has produced a number of distinct ecological species adapted to particular environments (some of these species have produced hybrids in captivity). To what extent the diversification of African viverrids is due to the fluctuation in tropical forested environments during the Quaternary glacial episodes remains an interesting and unresolved question.

The considerable diversity of paradoxures, hemigalines, and the viverrines Viverra and Viverricula, seems somehow linked to the episodic isolation of land areas in Indonesia and adjacent southeast Asia during the climatic oscillations of the late Cenozoic. On the other hand, the African viverrids Civettictis and Genetta, although widely distributed over the continent and exhibiting evident populational variation, are without the 
production of marked generic diversity equivalent to that seen in southeast Asian viverrids.

Malagasy viverrids include the cranially and dentally plesiomorphic species Fossa fossa and the highly derived and specialized Eupleres and Cryptoprocta, that are not in evidence anywhere outside Madagascar, and likely represent endemic lineages evolved in isolation on the island. An improved fossil record of viverrids from the Neogene of Eurasia and Africa will be necessary to understand the origins of these diverse viverrid subgroups.

\section{ACKNOWLEDGMENTS}

I am grateful to Dr. L. Ginsburg, Muséum National d'Histoire Naturelle, Paris, for permission to study the crania of Quercy aeluroids, and to Dr. N. Simmons, American Museum of Natural History, New York, for the loan of the skulls of Prionodon and Poiana, and for allowing the dissection of the auditory regions of representative individuals. My thanks to Dr. Bruce Patterson, Field Museum of Natural History, Chicago, for the opportunity to study the linsang material in their collections. For figure 1, I thank illustrator Angie Fox, University of Nebraska State Museum, Lincoln.

\section{REFERENCES}

Allen, J. A.

1924. Carnivora collected by the American Museum Congo Expedition. Bull. Am. Mus. Nat. Hist. 47(3): 73-281.

Bugge, J.

1978. The cephalic arterial system in carnivores, with special reference to the systematic classification. Acta Anat. 101: 45-61.

Dashzeveg, D.

1996. Some carnivorous mammals from the Paleogene of the Eastern Gobi Desert, Mongolia, and the application of Oligocene carnivores to stratigraphic cor-

Ewer, R. F. relation. Am. Mus. Novitates 3179: 14.

1973. The Carnivores. Ithaca, NY: Cornell Filhol, H. Univ. Press, 494 pp.

1880. Sur la découverte de mammifères nouveaux dans les dépôts de phosphates de chaux du Quercy. C. R. Acad. Sci., Paris 90: $1579-1580$.

Flower, W. H.

1869. On the value of the characters of the base of the cranium in the classification of the Order Carnivora. Proc. Zool. Soc. London 1869: 4-37.

Gregory, W. K., and M. Hellman

1939. On the evolution and major classification of the civets (Viverridae) and allied fossil and recent Carnivora: a phylogenetic study of the skull and dentition. Proc. Am. Philos. Soc. 81(3): 309-392.

Hunt, R. M., Jr.

1974. The auditory bulla in Carnivora: an anatomical basis for reappraisal of carnivore evolution. J. Morphol. 143: 21-76.

1987. Evolution of the aeluroid Carnivora: significance of auditory structure in the nimravid cat Dinictis. Am. Mus. Novitates 2886: $74 \mathrm{pp}$.

1991. Evolution of the aeluroid Carnivora: viverrid affinities of the Miocene carnivoran Herpestides. Am. Mus. Novitates 3023: 34 pp.

1996a. Biogeography of the Order Carnivora. In J. Gittleman (ed.), Carnivore Behavior, Ecology and Evolution 2: 485-541. Ithaca, NY: Cornell Univ. Press.

1996b. Basicranial anatomy of the giant viverrid from ' $E$ ' Quarry, Langebaanweg, South Africa. In K. Stewart and K. Seymour (eds.), Palaeoecology and $\mathrm{Pa}$ laeoenvironments of Late Cenozoic Mammals: Tributes to the Career of C.S. Churcher: 588-597. Toronto: Univ. Toronto Press.

1998. Evolution of the aeluroid Carnivora: diversity of the earliest aeluroids from Eurasia (Quercy, Hsanda-Gol) and the origin of felids. Am. Mus. Novitates 3252: $65 \mathrm{pp}$.

Kingdon, J.

1977. East African Mammals: An Atlas of Evolution in Africa. Vol. III(A), Carnivores. New York, NY: Academic Press, 476 pp.

Klaauw, C. J. van der

1922. Uber die Entwickelung des Entotympanicums. Tijdschr. Ned. Dierk. Vereen. 18: 135-174.

McKenna, M. C., and S. K. Bell

1997. Classification of Mammals Above the Species Level. New York: Columbia Univ. Press, 631 pp. 
Miller, M. E., G. C. Christensen, and H. E. Evans 1964. The Anatomy of the Dog. Philadelphia: W. B. Saunders, 941 pp.

Mivart, S t. G.

1882. On the classification and distribution of the Aeluroidea. Proc. Zool. Soc. London 1882: 135-208.

Nowak, R. M.

1991. Walker's Mammals of the World (5th ed.) 2: 1149-1151. Baltimore: Johns Hopkins Univ. Press.

Petter, G.

1963. Etude de quelques Viverridés (Mammifères, Carnivores) du Pleistocène inférieur du Tanganyika. Bull. Soc. Géol. Fr. (ser. 7) 5: 265-274.

1974. Rapports phylétiques des Viverridés (Carnivores fissipèdes). Les formes de Madagascar. Mammalia 38(4): 605636.

Pocock, R. I.

1908. Report upon a small collection of Mammalia brought from Liberia by Mr. Leonard Leighton. Proc. Zool. Soc. London 1907: 1037-1046.

1915a. On some of the external characters of the genus Linsang, with notes upon the genera Poiana and Eupleres. Ann. Mag. Nat. Hist. 16: 341-351.

$1915 \mathrm{~b}$. On the feet and glands and other external characters of the Viverrinae, with the description of a new genus. Proc. Zool. Soc. London 1915: 131-149.

1915c. On the feet and glands and other external characters of the paradoxurine genera Paradoxurus, Arctictis, Arctogalidia, and Nandinia. Proc. Zool. Soc. London 1915: 387-412.

1915d. On some external characters of Galidia, Galidictis, and related genera. Ann. Mag. Nat. Hist. 16: 351-356.

1915e. On some of the external characters of the palm-civet (Hemigalus derbyanus, Gray) and its allies. Ann. Mag. Nat. Hist. 16: 153-162.

1916a. The alisphenoid canal in civets and hyaenas. Proc. Zool. Soc. London 1916: 442-445. 1916b. On the course of the internal carotid artery and the foramina connected therewith in the skulls of the Felidae and Viverridae. Ann. Mag. Nat. Hist. 17: 261-269.

1933. The rarer genera of Oriental Viverridae. Proc. Zool. Soc. London 1933: 9691035.

Radinsky, L.

1975. Viverrid neuroanatomy: phylogenetic and behavioral implications. J. Mammal. 56(1): 130-150.

Rosevear, D. R.

1974. The Carnivores of West Africa. Br. Mus. (Nat. Hist.) Publ. 723: 220-228.

Simpson, G. G.

1945. The principles of classification and a classification of mammals. Bull. Am. Mus. Nat. Hist. 85: 350.

Teilhard de Chardin, $\mathrm{P}$.

1915. Les carnassiers des phosphorites du Quercy. Ann. Paléontol. 9(3,4): 1-90.

Wayne, R. K., R. E. Benveniste, D. N. Janczewski, and S. J. O'Brien

1989. Molecular and biochemical evolution of the Carnivora. In J. Gittleman (ed.), Carnivore behavior, ecology, and evolution 2: 465-494. Ithaca, NY: Cornell Univ. Press.

Wurster, D. H., and K. Benirschke

1968. Comparative cytogenetic studies in the Order Carnivora. Chromosoma 24: 336-382.

Wurster-Hill, D. H., and C. W. Gray

1975. The interrelationships of chromosome banding patterns in procyonids, viverrids, and felids. Cytogenet. Cell Genet. 15: 306-331.

Wyss, A. R., and J. J. Flynn

1993. A phylogenetic analysis and definition of the Carnivora. In F. S. Szalay, M. J. Novacek, M. C. McKenna (eds.), Mammal phylogeny (placentals) 3252. New York: Springer.

Recent issues of the Novitates may be purchased from the Museum. Lists of back issues of the Novitates and Bulletin published during the last five years are available at World Wide Web site http://nimidi.amnh.org. Or address mail orders to: American Museum of Natural History Library, Central Park West at 79th St., New York, NY 10024. TEL: (212) 769-5545. FAX: (212) 7695009. E-MAIL: scipubs@amnh.org 